\title{
Performance of broiler chickens administered graded levels of bitter kola (Garcinia kola, Heckel) as feed additive
}

Owen, O. J., Briggs, B. P. and *Gunn, H. H.

Department of Animal Science,

Rivers State University Nkpolu-Oroworukwo, Port Harcourt.

*Corresponding author: gunn.hollinshead@ust.edu.ng

\section{Abstract}

A study of 28 days (4 weeks) was carried out at the Poultry Section of Rivers State University, Nkpolu-Oroworukwo, Port-Harcourt Rivers State-Nigeria, to determine the effect of bitter kola (Garcinia kola, Heckel) powder as a growth promoter in broiler chicken diets. One hundred and forty-four (144) unsexed one day-old Anak strain broiler chicks were subjected to various concentrated levels of bitter kola at $T_{1}$ (control), $T_{2}(5 \mathrm{~g} / \mathrm{kg} f e e d), T_{3}(10 \mathrm{~g} / \mathrm{kg} f e e d)$, $T_{4}(15 \mathrm{~g} / \mathrm{kg}$ feed $)$, respectively using a Completely Randomized Design (CRD), with 36 birds/treatment and 12 birds/replicate. The parameters evaluated were weight gain, feed intake, feed conversion ratio and cost production. Data collected were subjected to Analysis of Variance (ANOVA). Results obtained indicated significant effect $(P<0.05)$ in all the growth parameters evaluated. The mean total feed intake was $12.00 \mathrm{~kg}, 11.85 \mathrm{~kg}, 12.50 \mathrm{~kg}$ and $11.55 \mathrm{~kg}$ respectively for $T_{1}, T_{2}, T_{3}$ and $T_{4}$. Mean total weight gain was highest in $T_{4}(2.91 \mathrm{~kg})$ and least in $T_{1}(2.57 \mathrm{~kg})$. On feed conversion ratio, $T_{4}$ recorded the best with 3.97 . It was therefore advocated that bitter kola should be included in broiler diets as a feed additive to improve broiler chicken performance.

Keywords: Bitter kola, Broiler chicken, feed intake, Weight gain, Production cost

\section{Introduction}

Bitter kola (Garcinia kola, Heckel) tree belongs to the botanical family of Guttiferae (Plowden, 1992). It is a mediumsized rain forest tree crop, well cultivated through West Indies, West and Central Africa (Iwu et al., 1990). The bitter kola fruit is used as food and herbal medicine and produces reddish, yellowish or orange seeds when ripe, containing two to four seeds. Each fruit contains about 6-8 smooth elliptically shaped seeds with brown coat. Bitter kola (Garcinia spp) is known to have an elaborate complex mixture of phenolic compounds including bioflavonoids, xanthones and benzophenones. Adegboye et al. (2008) tested for the presence of alkaloids, steroids, cardiac glycosides, flavonoids, tannins, saponins and reducing sugar in bitter kola. All the phytochemical compounds tested for were found present except alkaloids. Also bitter kola was reported to contain in $\mathrm{g} / 100 \mathrm{~g}$ tannin- 0.342 \pm 0.00 , oxalate- $0.423 \pm 0.00 \mathrm{~g}$, phytate$0.570 \pm 0.05$, trypsin inhibitor- $0.370 \pm$ 0.12 , phenol- $0.147 \pm 0.00$, saponin- $2.471 \pm$ 0.00 , alkaloids- $0.647 \pm 0.20$, flavonoids $2.041 \pm 0.30$ and glycosides $3.421 \pm 0.00$ (Adesuyi et al., 2012). The major active constituents (alkaloids and flavonoids) of bitter kola were reported to stimulate an increase in gastric acid secretion (Oluwole and Obtatomi, 1991). Bitter kola was reported to contain $0.58 \%$ crude protein, $0.10 \%$ crude fibre, $3 \%$ ether extract, $5 \%$ crude ash and $72.72 \%$ nitrogen free extract (Ibekwe and Orok, 2010). Odebunmi et al. (2009) reported fresh bitter kola to have $39.52 \pm 0.06 \%$ dry matter, $4.51 \pm 0.56 \%$ crude fat, $2.48+0.10 \%$, crude protein, 0.79 $\pm 0.005 \%$ ash, $5.23 \pm 0.16 \%$ crude fibre and $35.64 \%$ total carbohydrates. The following mineral compositions from bitter kola were also reported in $\mathrm{mg} / \mathrm{Kg}$ : $\mathrm{K}-722.10 \pm 0.00$, $\mathrm{Ca}-67.07 \pm 0.12, \mathrm{Mg}-114.83 \pm 3.47$, Fe$6.10 \pm 0.43, \mathrm{Zn}-2.30 \pm 0.08, \mathrm{Mn}-\mathrm{not}$ 
detectable, P-188.57 \pm 0.37 (Odebunmi et al., 2009). Adesuyi et al., (2012) also reported the following proximate chemical composition for bitter kola: moisture content- $7.2 \pm 0.08 \%$, crude protein- $1.86 \pm$ $0.15 \%$, crude fibre- $1.23 \pm 0.15 \%$, ash -0.47 $\pm 0.09 \%$, crude fat- $0.19 \pm 0.32 \%$, carbohydrate- $88.30 \pm 0.08 \%$. Garcinia kola increases the activities of the enzymes lactate dehydrogenase and glucose -6phosphate dehydrogenase. Bitter kola has been reported to contain phytochemical components (Iwu et al., 1990) that may be useful to animal performance hence its justification for inclusion in this research. Therefore, this study investigated the effect of bitter kola as feed additive in a broiler diets at different graded level.

\section{Materials and methods}

The experiment was carried out at the poultry production section of Teaching and Research farm of the Rivers State University, Rivers state Nigeria.

The fresh bitter kola seeds were purchased from a local market (Oil mill) Rumuchorlu in Obio/Akpor Local Government Area of Rivers State, Nigeria. Bitter kola seeds were sliced, and air dried for 21days. The soft brown testa was then removed before grinding into powdered form. It was incorporated into top feed finisher feed with protein content of $18 \%$ and energy content of $2900 \mathrm{Kcal} / \mathrm{kg}$ ME. One hundred and forty-four (144) unsexed one day-old broiler chicks were allocated randomly to pens. The breed used for this experiment was of Anak Strain sourced from Zartech Hatchery in Oyo State. Water and feed were offered ad-libitum with routine vaccinations and medications administered strictly during the study. Powdered bitter kola was incorporated into proprietary broiler finisher mashes at graded levels with $0 \mathrm{~g}$ bitter kola $/ \mathrm{kg}$ of feed which served as control while treatments 1,2 and 3 had
$5 \mathrm{~g} / \mathrm{kg}, 10 \mathrm{~g} / \mathrm{kg}$ and $15 \mathrm{~g} / \mathrm{kg}$ of feed, respectively as diet inclusions. There were four treatments with three replications, each treatment had thirty-six (36) birds with twelve (12) birds in each replicate distributed into twelve (12) pens and well tagged according to treatment. The design of the experiment was Completely Randomized Design (CRD). The study lasted 28 days. At the onset of the experiment mean initial body weight of the birds were measured and recorded. Mortality was recorded as it occurred. The parameters evaluated were weight gain, feed intake, feed conversion ratio and cost of feed consumed. Feed intake was measured on daily basis and obtained by subtracting the left-over from the feed given; the sum total was done every week. The birds were weighed in groups to determine the body weight. Weight gain was obtained by subtracting the initial weight from the final weight. The feed conversion ratio was measured as total feed intake over total weight gain. The data collected were subjected to Analysis of Variance (ANOVA), (Steel and Torrie, 1980) and the differences between treatment means where they existed were separated using Duncan's New Multiple Range Test (DNMRT).

\section{Results and discussion}

The effect of bitter kola (Garcinia kola, Heckel) as a growth promoter on broiler chickens are presented in the Table 1 below. The results obtained showed that significant differences $(\mathrm{P}<0.05)$ existed in all the parameters measured in relation to final body weight, body weight gain, and feed conversion ratio and no significant differences $(\mathrm{P}>0.05)$ existed in feed intake. The mean final body weights for the birds were $2.65 \mathrm{~kg}, 2.80 \mathrm{~kg}, 2.85 \mathrm{~kg}$ and $3.00 \mathrm{~kg}$ for $\mathrm{T}_{1}$ (control), $\mathrm{T}_{2}, \mathrm{~T}_{3}$ and $\mathrm{T}_{4}$, respectively. The highest final weight was recorded in $\mathrm{T}_{4}$ and 


\section{Owen, Briggs and Gunn}

was least in $T_{1}$ which is the control with comparable final weights in $\mathrm{T}_{2}$ and $\mathrm{T}_{3}$. The mean total body weight gain for the birds were $2.57 \mathrm{~kg}, 2.72 \mathrm{~kg}, 2.77 \mathrm{~kg}$ and $2.91 \mathrm{~kg}$, respectively for $T_{1}$ (control), $T_{2}, T_{3}$ and $T_{4}$. The highest mean total body weight gain was recorded in $\mathrm{T}_{4}(15 \mathrm{~g} / \mathrm{kg})$ and was least in $\mathrm{T}_{1}$ (control), while comparable weight gains were observed in $\mathrm{T}_{2}, \mathrm{~T}_{3}$. The results on mean total feed intake showed no significant $(\mathrm{P}>0.05)$ difference between the control and the treated groups and were observed as $12.00 \mathrm{~kg}, 11.85 \mathrm{~kg}, 12.50 \mathrm{~kg}$ and $11.55 \mathrm{~kg}$, respectively for $\mathrm{T}_{1}$ (control), $\mathrm{T}_{2}, \mathrm{~T}_{3}$ and $\mathrm{T}_{4}$. The highest feed intake was recorded in $\mathrm{T}_{3}$ $(10 \mathrm{~g} / \mathrm{kg})$ while the least was observed in $\mathrm{T}_{4}$ $(15 \mathrm{~g} / \mathrm{kg})$ and $\mathrm{T}_{2}(5 \mathrm{~g} / \mathrm{kg})$. Feed conversion ratio (feed intake/weight gain) was superior in $\mathrm{T}_{4}(15 \mathrm{~g} / \mathrm{kg})$ and the least feed conversion ratio was observed in the $T_{1}$ (control). Data on feed conversion ratio ranged from 3.97-
4.67. The results on the cost of feed showed that $\mathrm{T}_{1}$ (control), $\mathrm{T}_{2}, \mathrm{~T}_{3}, \mathrm{~T}_{4}$ recorded $\mathrm{N} 1248.00, \mathrm{~N} 1235.25, \mathrm{~N} 1305.70$ and N1209.75 respectively. This showed that $\mathrm{T}_{4}$ $(15 \mathrm{~g} / \mathrm{kg})$ had the least cost of production while the highest cost of feed production was recorded in $T_{3}(10 \mathrm{~g} / \mathrm{kg})$. This equally reflected in the total feed consumed.

The results from this experiment indicated that broilers had better growth performance potentials in terms of final weight, weight gain, feed intake, feed conversion ratio and feed cost of production when dried bitter kola was added to the proprietary feed as a feed additive at $15 \mathrm{~g} / \mathrm{kg}$ level over the control for 28 days (4 weeks). Reported literature has suggested that plant materials enhance the secretion of endogenous digestive enzymes and activate the immune response and antioxidant activities (Jamroz etal., 2003).

Table 1: The effect of b itter kola (Garcinia kola, Heckel) on the performance characteristics of broiler chickens

\begin{tabular}{llllll}
\hline Parameters & \multicolumn{5}{c}{ Treatment } \\
\cline { 2 - 5 } & $\mathrm{T}_{1}(0 \mathrm{~g} / \mathrm{kg})$ & $\mathrm{T}_{2}(5 \mathrm{~g} / \mathrm{kg})$ & $\mathrm{T}_{3}(10 \mathrm{~g} / \mathrm{kg})$ & $\mathrm{T}_{4}(15 \mathrm{~g} / \mathrm{kg}$ & SEM \\
\hline Mean initial weight $(\mathrm{kg})$ & 0.87 & 0.83 & 0.85 & 0.81 & - \\
Mean final weight $(\mathrm{kg})$ & $2.65^{\mathrm{c}}$ & $2.80^{\mathrm{bc}}$ & $2.85^{\mathrm{b}}$ & $3.00^{\mathrm{a}}$ & 0.06 \\
Mean total weight gain $(\mathrm{kg})$ & $2.57^{\mathrm{c}}$ & $2.72^{\mathrm{bc}}$ & $2.77^{\mathrm{b}}$ & $2.91^{\mathrm{a}}$ & 0.04 \\
Mean daily weight gain $(\mathrm{g})$ & $91.79^{\mathrm{c}}$ & $97.14^{\mathrm{bc}}$ & $98.93^{\mathrm{b}}$ & $103.93^{\mathrm{a}}$ & 0.86 \\
Mean total feed intake $(\mathrm{kg})$ & 12.00 & 11.85 & 12.50 & 11.55 & 0.13 \\
Mean daily feed intake $(\mathrm{g})$ & 428.60 & 423.20 & 446.40 & 412.50 & 2.05 \\
Feed conversion ratio & 4.67 & 4.36 & 4.51 & 3.97 & 0.05 \\
Cost of feed without B. kola/Kg $(\mathbb{K})$ & 1248.00 & 1232.40 & 1300.00 & 1201.20 & - \\
Cost of feed with B. kola/Kg & 1248.00 & 1266.17 & 1371.25 & 1299.95 & - \\
Mortality & 3 & 0 & 1 & 2 & 0 \\
\hline
\end{tabular}

${ }^{a b c}$ Means within a row with different superscripts differ significantly at $(P<0.05)$. SEM: Standard Error mean

Also better feed conversion ratio obtained from broilers fed dried bitter kola diet could be compared with the work of Adedeji et al. (2006) who obtained highest $(\mathrm{P}<0.05)$ feed efficiency from broiler chicks fed $25 \mathrm{~g}$ per $\mathrm{Kg}$ diet dried bitter kola over other broiler chickens without bitter kola in their diets. In addition, the better weight gain obtained from broiler chickens fed dried bitter kola in this study could be compared with the work of Dada and Ikuerowo (2009) that fish fed $1 \mathrm{~g} / \mathrm{kg}$ diet ethalonic extract of bitter kola had best $(\mathrm{P}<0.05)$ weight gain than those fed the control diet and $0.25,0.5$ and $2 \mathrm{~g} / \mathrm{kg}$ diet ethanolic extract of bitter kola. This result is contrary to what was obtained 
in this study. This may be due to the form of bitter kola used (seed powder), the amount of the bitter kola administered to the animals and the variation in the species of the animals. On the other hand, enhanced growth performance was also reported in poultry (Adedeji et al., 2006) and rats (Oluyemi et al., 2007) fed diets containing bitter kola extracts.

\section{Conclusion}

Though, the possible mode of action of bitter kola was not explored in this study, it is concluded that air dried grounded bitter kola must have some active components that might have enhanced the physiology of the birds that fed on it to give them their superior performances. Also, 5-15g bitter $\mathrm{kola} / \mathrm{Kg}$ feed can be used in broiler chicken finisher diets in order to improve performance and better cost of feed production. Further research should be conducted to explore the possible mode of action of 5-15g bitter kola/ Kg feed on the physiology of broiler birds as it would serve as useful information for feed resources and nutrition.

\section{References}

Adedeji, O. S., Farinu, G. O., Ameen, S. A. and Olayeni, T. B. 2006. The effects of dietary bitter kola (Garcinia kola) Inclusion on body weight, haematology and survival rate of pullets chicks. J. Anim. Vet. $A d v$, 5(3), 184-187. Retrieved from .

Adegboye, M. F., Akinpelu, D. A. and Okoh, A. I. 2008. The bioactive a n d p hy toc he m i c a l properties of Garcinia kola (Heckel) seed extract on some pathogens. African Journal of Biotechnology Vol. 7 (21), pp.
3934-3938. Retrieved from http://www.academicjournals . \begin{tabular}{llllllll}
\hline & $\mathrm{r}$ & $\mathrm{g}$ & $/$ & $\mathrm{A}$ & $\mathrm{J}$ & $\mathrm{B}$ &
\end{tabular} http://dx.doi.org/10.5897/AJB08. $\underline{586 .}$.

Adesuyi, A. O., Elumm, I. K., Adaramola, F. B. and Nwokocha, A .G. M. 2012. Nutritional and Phytochemical Screening of Garcinia kola. Advance Journal of Food Science and Technology, s4(1), 9-14.

Ibekwe, H. A. and Orok, E. E. 2010. Proximate Composition of Aframomum Melegueta Seeds, Garcinia kola Seeds and Growth Performance of Broiler Chicks treated with Powders from these Seeds. International Journal of Poultry Science, 9(12), 1152-1155.

Iwu, M. M., Igboko, A. O. and Tempesta, M. S. 1990. Antidiabetic and aldose reductase activities of biflavanones of Garcinia kola. Fitoterapia, $\operatorname{LXi}(1), 178$.

Jamroz, D., Orda, J., Kamel, C., WiliczKiewicz, A., Wertelccki, T. and Skorupinska, J. 2003. The influence of phytogenetic extracts on performance, nutrient digestibility, carcass characteristics and gut microbial status in broiler chickens. J. Ani. Feed-Sci., 12:583-596.

Odebunmi, E. O., Oluwaniyi, O. O., Awolola, G. V. and Adediji, O. D. 2009. Proximate and nutritional composition of kola nut (Cola nitida), bitter cola (Garcinia cola) and alligator pepper (Afromomum melegueta). African Journal of Biotechnology, 8(2), 308-310. http://www.academicjournals.org/ AJB

Oluyemi, A. K., Omotuyi, O. I., Jimoh, R. O., Adesanya, A. O., Saalu, C. L. 
and Josiah, L. S. 2007. Plowden, C. C. 1992. A manual of plants Biotechnol. Appl. Biochem, 46, 69 -72 . names 3rd edition., London geroge Ltd. Pp 239.

Oluwole, F. S. and Obtatomi, A. B. 1991. Steel, R. G. D. and Torrie J. H. 1980. The effect of Garcinia kola seed on Gastric acid secretion in albino rats. Nig. J. Physio Sci, 8, 75-80. Principles and procedures of Statistics. A biometric Approach. $2^{\text {nd }}$ Ed. Mc Graw-Hill Book Co.

Received: $24^{\text {th }}$ July, 2019

Accepted: $18^{\text {th }}$ December, 2019 